Dublin Institute of Technology

ARROW@DIT

Articles

Crest: Centre for Research in Engineering Surface

Technology

2004-01-01

\title{
Microstructural Analysis of Varistors Prepared from Nanosize $\mathrm{ZnO}$
}

Suresh Pillai

Dublin Institute of Technology, suresh.pillai@dit.ie

Declan McCormack

John Kelly

Ramesh Raghavendra

Follow this and additional works at: http://arrow.dit.ie/cenresart

Part of the Nanoscience and Nanotechnology Commons

\section{Recommended Citation}

Pillai, S C*, Kelly, J M, McCormack, D E, and Ramesh, R. Microstructural analysis of varistors prepared from nano-size ZnO, Journal of Materials Science and Technology August 2004 Vol. 20, 964-968.

This Article is brought to you for free and open access by the Crest: Centre for Research in Engineering Surface Technology at ARROW@DIT. It has been accepted for inclusion in Articles by an authorized administrator of ARROW@DIT. For more information, please contact

yvonne.desmond@dit.ie, arrow.admin@dit.ie.

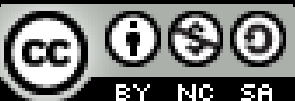




\title{
Microstructural analysis of varistors prepared from nanosize ZnO
}

\author{
S. C. Pillai, J. M. Kelly, D. E. McCormack and R. Ramesh
}

$\mathrm{ZnO}$ nanoparticles were prepared by a solid state pyrolysis reaction of zinc acetate dihydrate and oxalic acid dihydrate at $500 \mathrm{C}$. The course of reaction at various temperatures was followed by XRD. Subsequently varistors were fabricated from this nano- $\mathrm{ZnO}$ material by solid state mixing with various oxide additives and sintering to $1050^{\circ} \mathrm{C}$. The microstructure of the sintered material was studied using XRD, field emission SEM (FESEM), and EDX, and $\mathrm{ZnO}$ grains, bismuth rich regions and spinel phases were identified. Discs made from oxide doped nano$\mathrm{ZnO}$ show considerably higher breakdown voltage $\left(656 \pm 30 \mathrm{~V} \mathrm{~mm}^{-1}\right)$ compared to those prepared from micrometre sized $\mathrm{ZnO}\left(410 \pm 30 \mathrm{~V} \mathrm{~mm}^{-1}\right)$ and commercial varistors $\left(454 \pm 30 \mathrm{~V} \mathrm{~mm} \mathrm{~mm}^{-1}\right)$. However, varistors made from the nano- $\mathrm{ZnO}$ show very low densification and high leakage current, making them unsuitable for device fabrication.

MST/6097

Keywords: Nanostructures, Zinc oxide, Varistors, Breakdown voltage

Dr Pillai is in the Department of Chemistry, The University of Dublin, Trinity College, Dublin 2, Ireland and in the Centre for Research in Engineering Surface Technology (CREST), Dublin Institute of Technology, Camden Row, Dublin 8, Ireland (suresh.pillaisc@dit.ie).Professor Kelly is in the Department of Chemistry, The University of Dublin, Trinity College, Dublin 2 , Ireland. Dr McCormack is in the School of Chemistry Dublin Institute of Technology, Kevin Street, Dublin 8, Ireland. Dr Ramesh is with Littelfuse Ireland Ltd., Ecco Road, Dundalk, Co. Louth, Ireland. Revised version of a presentation at 'Nanomaterials and nanomanufacturing' held in London on 15-16 December 2003; accepted 8 April 2004.

(C) 2004 IoM Communications Ltd. Published by Maney for the Institute of Materials, Minerals and Mining.

\section{Introduction}

$\mathrm{ZnO}$ varistors are well known electroceramic devices, which have voltage dependent switching capabilities. ${ }^{1-4}$ Varistors are usually connected across the power line in parallel with the instrument to be protected from overvoltage surges. ${ }^{3}$ These devices are highly resistive up to a certain field (breakdown voltage, $V_{\mathrm{c}}$ ), above which they become highly conducting. When the voltage exceeds $V_{\mathrm{c}}$, the varistor starts conducting and draws current through it. At present, varistors are used for overvoltage protection in many electrical and electronic networks at voltages ranging from $12 \mathrm{~V}$ to over $10^{6} \mathrm{~V} .^{5}$ As a result of the demand for miniaturised devices, it is essential to provide voltage surge absorbers of a similar scale. ${ }^{6}$ It should be noted that careful control of the microstructure is required to produce varistors with a high breakdown voltage as $V_{\mathrm{c}}$ is proportional to the number of active grain boundaries in the sintered body. ${ }^{1,3,6,7}$ In principle, it should be possible, through nanostructuring, to produce $\mathrm{ZnO}$ varistors with a high $V_{\mathrm{c}}$ by controlling the grain size and hence the increased number of active grain boundaries per unit volume in the material. Nano-ZnO prepared through different routes including sol-gel, ${ }^{6-9}$ precipitation, ${ }^{10,11}$ microemulsion ${ }^{12}$ and plasma synthesis ${ }^{13}$ were some of the early methods attempted to make materials for varistor applications. It has recently been observed that nano- $\mathrm{ZnO}$ material, ${ }^{6}$ prepared from zinc acetate and oxalic acid through a multistep solution route, can be used to produce varistor materials with markedly improved breakdown voltage. The aim of this work was to prepare nano- $\mathrm{ZnO}$ in an environmentally friendly (solvent free) fashion and to prepare the varistors by sintering at a low temperature. Recently nano-ZnO has been successfully prepared by solid state pyrolysis ${ }^{14,15}$ and used for making a gas sensor ${ }^{14}$ and UV emitter. ${ }^{15}$ In this paper nano-ZnO has been prepared by the previously reported solid state pyrolysis procedure ${ }^{14}$ and varistors have been fabricated by incorporating various additives, and sintering at $1050^{\circ} \mathrm{C}$. These samples are compared to others prepared from micrometre sized $\mathrm{ZnO}$.

\section{Experimental}

\section{MATERIALS}

Zinc acetate dihydrate (Riedel-de Haen, 99.5\%) and oxalic acid dihydrate (Aldrich, 99\%) are used as received. Micron sized $\mathrm{ZnO}$ (Grillo), $\mathrm{Bi}_{2} \mathrm{O}_{3}$ (Ferro corporation), $\mathrm{Sb}_{2} \mathrm{O}_{3}$ (Cookson), $\mathrm{CoO}$ (Outokumpu), $\mathrm{MnO}$ (Campbell Chemicals), $\mathrm{NiO}$ (Campbell Chemicals), $\mathrm{Cr}_{2} \mathrm{O}_{3}$ (Merck), $\mathrm{Al}_{2} \mathrm{O}_{3}$ (Merck) (all reagent grade) and commercial varistor powder were supplied by Littelfuse Ltd, Dundalk.

\section{PREPARATION OF NANO-ZnO}

Zinc oxide nanoparticles were prepared by a solid state pyrolysis technique using zinc acetate and oxalic acid. ${ }^{14,15}$ In a typical experiment $10.98 \mathrm{~g}(50 \mathrm{mmol})$ zinc acetate dihydrate and $12.6 \mathrm{~g} \mathrm{(100} \mathrm{mmol)} \mathrm{oxalic} \mathrm{acid} \mathrm{dihydrate} \mathrm{were}$ mixed in an agate mortar for $3 \mathrm{~min}$. This mixture was then calcined by heating from room temperature to $500^{\circ} \mathrm{C}$ using a ramp rate of $3 \mathrm{~K} \mathrm{~min}^{-1}$ and held at this temperature for $2 \mathrm{~h}$ in a chamber furnace to yield nanosized particles of $\mathrm{ZnO}$ (nano- $\mathrm{ZnO}$ ).

\section{ADDITION OF DOPANTS TO NANO-ZnO}

$\mathrm{ZnO}$ was mixed with commercial oxide additives by a solid state mixing technique. In a typical experiment nano- $\mathrm{ZnO}$ $(2.000 \mathrm{~g}, 24.500 \mathrm{mmol})$ calcined at $500^{\circ} \mathrm{C}$ was added to $\mathrm{Bi}_{2} \mathrm{O}_{3} \quad(0.060 \mathrm{~g}, \quad 0.1300 \mathrm{mmol}), \quad \mathrm{Sb}_{2} \mathrm{O}_{3} \quad(0.0940 \mathrm{~g}$, $0.3200 \mathrm{mmol}), \quad \mathrm{MnO} \quad(0.0220 \mathrm{~g}, 0.2500 \mathrm{mmol}), \mathrm{NiO}$ $(0.0120 \mathrm{~g}, \quad 0.1600 \mathrm{mmol}), \quad \mathrm{CoO}(0.021 \mathrm{~g}, 0.280 \mathrm{mmol})$, $\mathrm{Cr}_{2} \mathrm{O}_{3} \quad(0.0196 \mathrm{~g}, \quad 0.130 \mathrm{mmol})$ and $\mathrm{Al}_{2} \mathrm{O}_{3} \quad(0.0005 \mathrm{~g}$, $0.0047 \mathrm{mmol}$ ) and mixed in an agate mortar for $5 \mathrm{~min}$. This mixture was plastified by mixing with one drop each of $10 \%$ aqueous solution of poly(vinyl alcohol), poly(ethylene glycol) and $0.015 \mathrm{~g}$ of gum arabic. The material was then dried, pelletised and sintered at $1050^{\circ} \mathrm{C}$ for $2 \mathrm{~h}$. Varistors were also made by mixing micrometre sized $\mathrm{ZnO}$ (micron$\mathrm{ZnO}$ ) with oxide additives in a similar way. Solid 


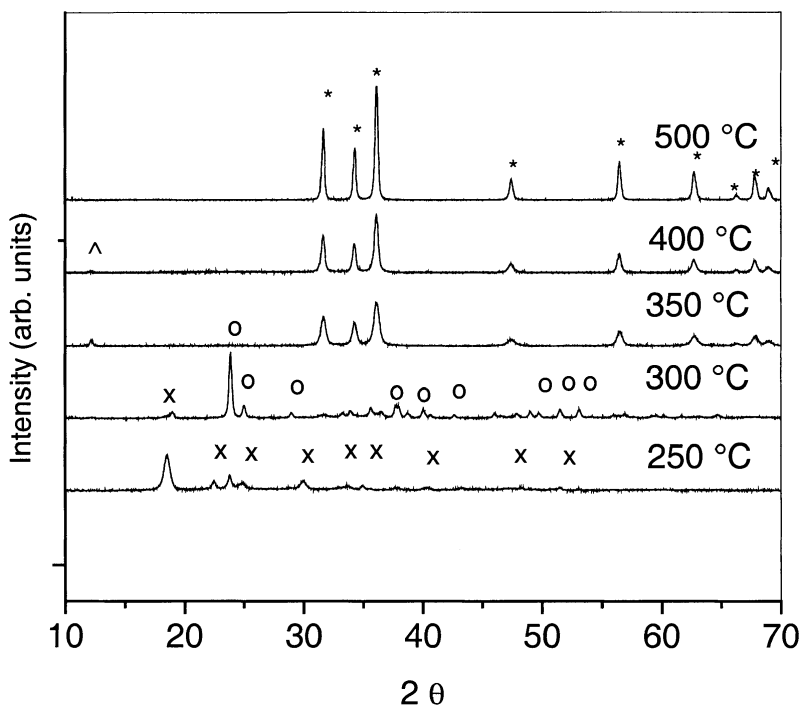

1 XRD pattern of $\mathrm{ZnO}$ precursors calcined at various temperatures: ( $x$ zinc oxalate dihydrate; $o$ anhydrous zinc oxalate, $\wedge$ unidentified phase; ${ }^{*} \mathrm{ZnO}$ )

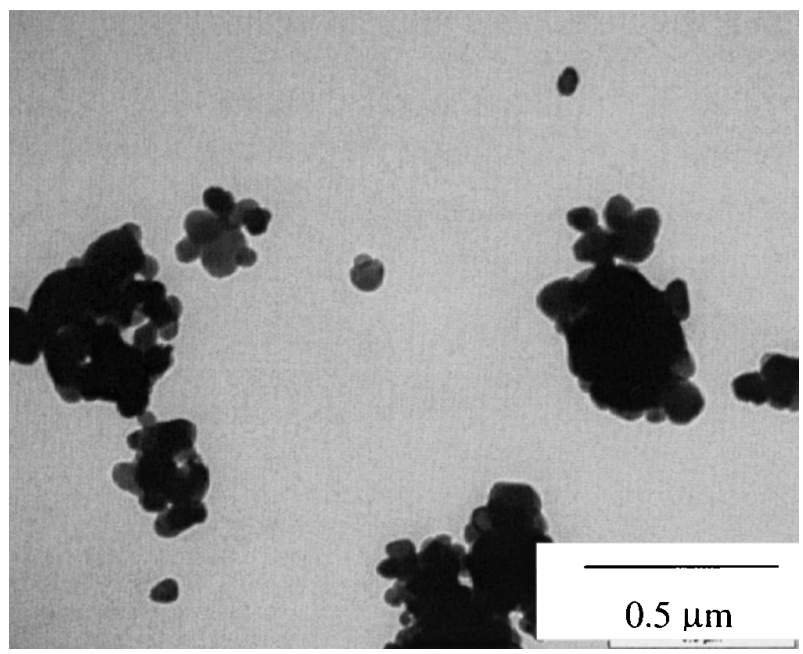

2 TEM image of nano-ZnO sample calcined at $500^{\circ} \mathrm{C}$

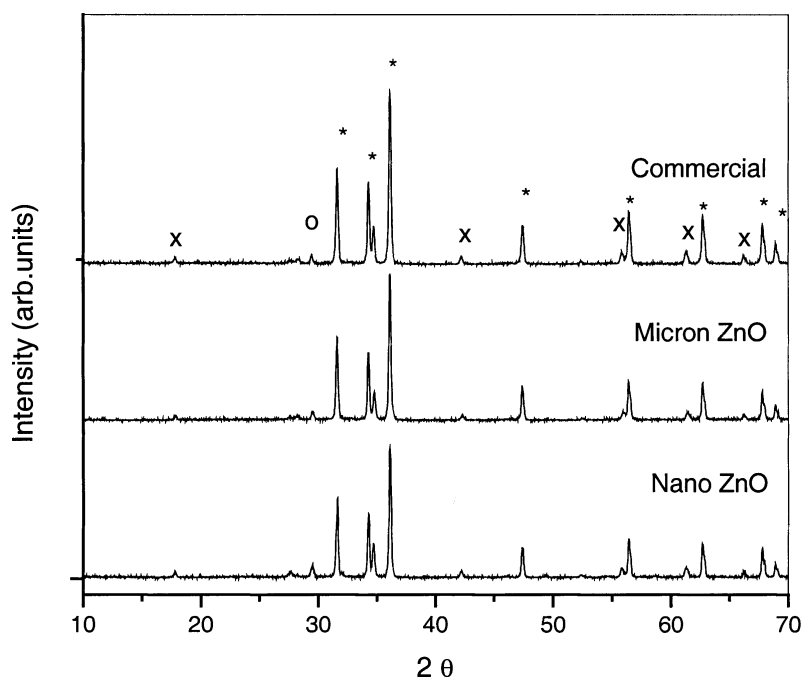

3 XRD pattern of sintered $\left(1050^{\circ} \mathrm{C}\right)$ varistor samples (* $\mathrm{ZnO} ; \mathrm{x} \mathrm{Zn}_{7} \mathrm{Sb}_{2} \mathrm{O}_{12} ; 0 \mathrm{Bi}_{2} \mathrm{O}_{3}$ )

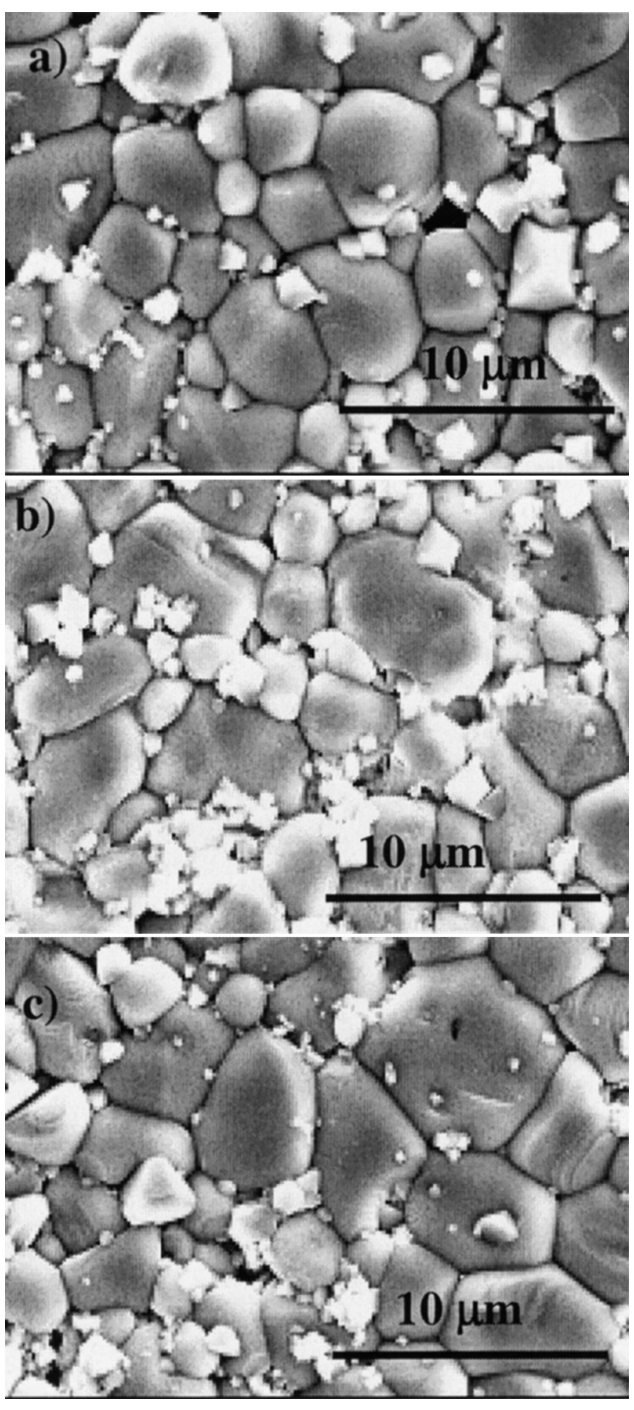

a prepared from nano- $\mathrm{ZnO} ; b$ prepared from micrometre- $\mathrm{ZnO}$; $c$ commercial varistor

4 FESEM images of sintered surface (not etched) at 1050 C differently prepared varistors

state pyrolysis reaction, calcination, and sintering were performed in a Nabertherm S-27, chamber furnace.

\section{INSTRUMENTATION}

Samples for powder X-ray diffraction (XRD) were prepared by making a thin layer of the powder with acetone on a glass plate and the measurements were performed with a Siemens D 500 X-ray diffractometer. The particle size was calculated by applying the Scherrer equation ${ }^{16}$

$$
\text { crystalline size }=\frac{0 \cdot 9 \lambda}{B \cos \theta}
$$

where $\lambda=\mathrm{X}$-ray wavelength, $\theta=$ Bragg angle, $B=$ line broadening. The line broadening $B$ is measured from the increased peak width at half the peak height and is obtained from the Warren formula $B^{2}=B_{\mathrm{M}}^{2}-B_{\mathrm{S}}^{2}$ where $B_{\mathrm{M}}$ is the measured peak width and $B_{\mathrm{S}}$ is the corresponding width of a peak of a standard material (commercial $\mathrm{ZnO}$ ) whose particle size is greater than $200 \mathrm{~nm}$.

$I-V$ characteristics from $0 \cdot 1 \mu \mathrm{A}$ to $1 \mathrm{~mA}$ were measured using a Keithley Instruments (Model 2410, Sourcemeter). The breakdown voltage $V_{\mathrm{c}}$ is given as the nominal voltage at a current of $1 \mathrm{~mA}$. 

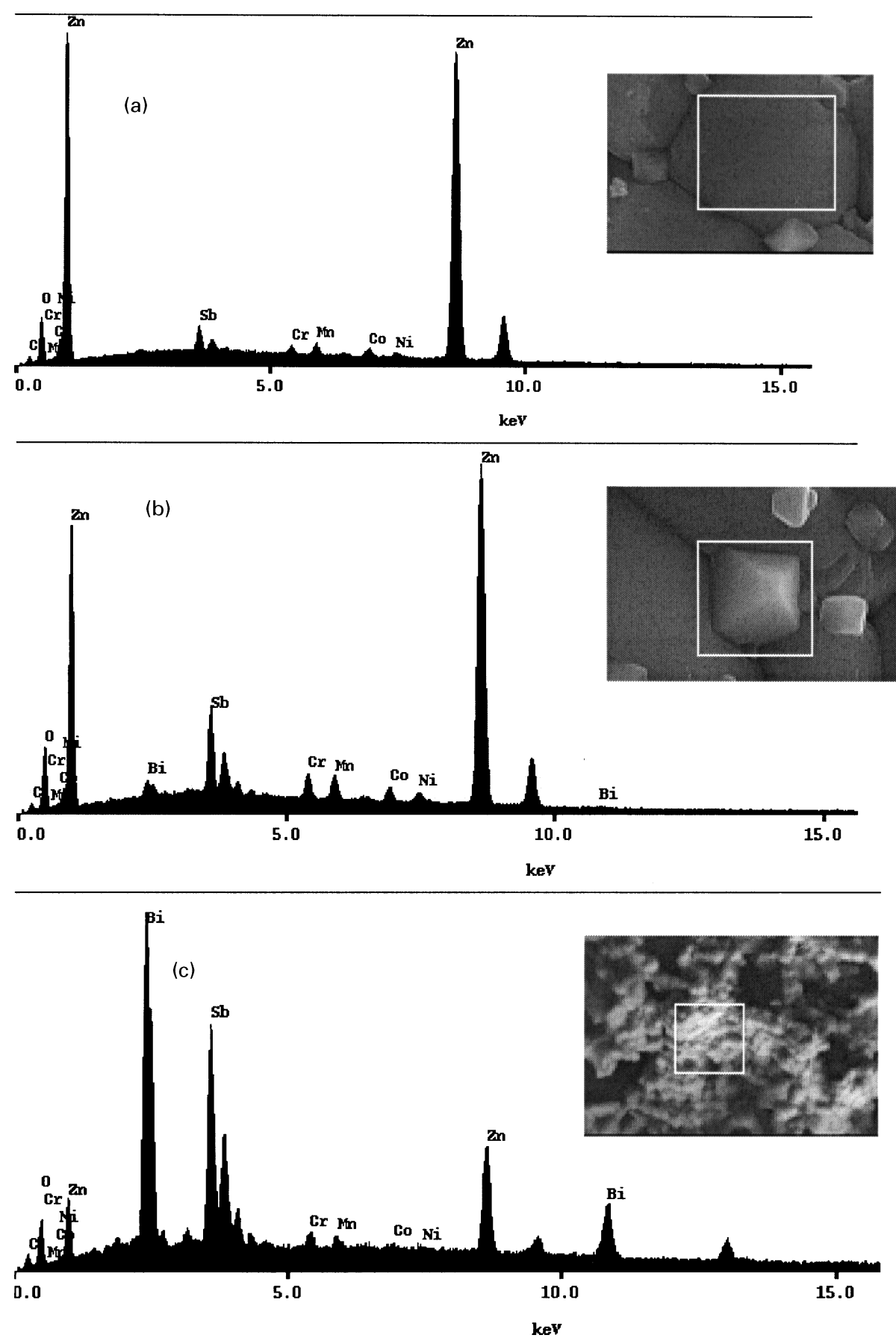

a ZnO grain; $b$ spinel phase; $c$ bismuth rich area

5 EDX analysis of varistor prepared from nano-ZnO (sintered at $1050^{\circ} \mathrm{C}$ )

Transmission electron microscopy (TEM) was performed using a Hitachi 7000 TEM instrument. 300 mesh copper grids coated with formvar were used to prepare the samples.

Scanning electron microscopy (SEM) and energy dispersive X-ray (EDX) studies were carried out by field emission scanning electron microscopy (FESEM, Hitachi S-4300), which was operated at 5 or $20 \mathrm{kV}$. Samples for analysis were mounted on aluminium stubs and were coated with graphite.

\section{Results and discussion}

\section{PREPARATION AND CHARACTERISATION OF NANO-ZnO}

Zinc oxide nanoparticles were prepared by mixing zinc acetate dihydrate and oxalic acid dihydrate and heating to $500^{\circ} \mathrm{C}^{14}$
Using thermogravimetric analysis (TGA) Shen et al. ${ }^{14}$ proposed that in this reaction the $\mathrm{ZnO}$ is formed via zinc oxalate hydrate. XRD analysis was carried out at various stages of the reaction at different temperatures starting from $250^{\circ} \mathrm{C}$. The XRD pattern (Fig. 1) of the precursor powder calcined at $250^{\circ} \mathrm{C}$ showed that zinc oxalate dihydrate (Joint Committee on Powder Diffraction Standard (JCPDS) card no. 25-1029) is the predominant phase with traces of anhydrous zinc oxalate (JCPDS card no. 37-0718). ${ }^{6,17}$ The pattern at $300^{\circ} \mathrm{C}$ matches the JCPDS data of anhydrous zinc oxalate with a very weak peak of zinc oxalate dihydrate. ${ }^{6,17}$ These results are similar to earlier observations ${ }^{6}$ with a $\mathrm{ZnO}$ sample prepared through a solution route, except that anhydrous zinc oxalate was already formed at $250^{\circ} \mathrm{C}$. $\mathrm{ZnO}$ is formed at $350^{\circ} \mathrm{C}$ with a very small percentage of impurity (unidentified phase) and this has fully vanished in samples calcined at $500^{\circ} \mathrm{C}$ 


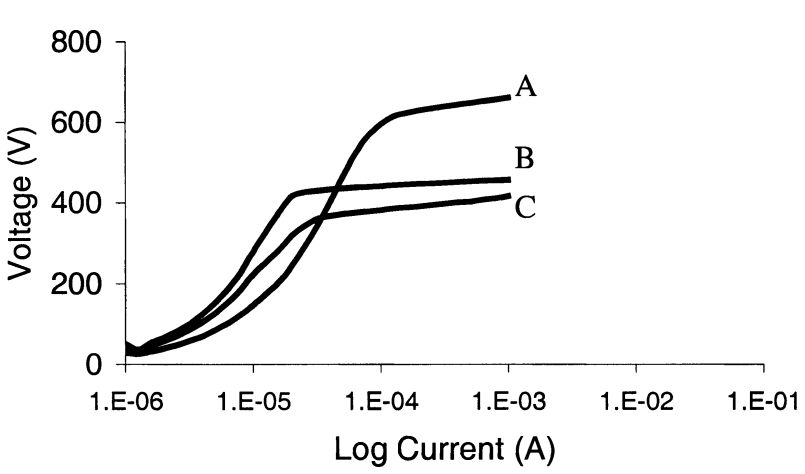

A: varistors prepared from nano- $\mathrm{ZnO}$; $\mathrm{B}$ : commercial varistor supplied by Littelfuse Ireland Ltd; C: varistors prepared from micrometre-ZnO

6 I- $V$ curve of varistor samples sintered at $1050^{\circ} \mathrm{C}$ for $2 \mathrm{~h}$

Broadening of the larger XRD intensity peak (101, $2 \theta=36 \cdot 2^{\circ}$ ) of the sample at $500^{\circ} \mathrm{C}$ shows this nano- $\mathrm{ZnO}$ sample has an average particle size of $40 \pm 8 \mathrm{~nm}$ and this is reasonably consistent with TEM analysis (Fig. 2) which gives an average diameter of $61 \pm 10 \mathrm{~nm}$.

\section{VARISTOR PREPARATION AND MICROSTRUCTURE ANALYSIS}

Nano-ZnO was mixed with commercial oxide additives $\left(\mathrm{Bi}_{2} \mathrm{O}_{3}, \mathrm{Sb}_{2} \mathrm{O}_{3}, \mathrm{CoO}, \mathrm{MnO}, \mathrm{NiO}, \mathrm{Cr}_{2} \mathrm{O}_{3}\right.$ and $\left.\mathrm{Al}_{2} \mathrm{O}_{3}\right)$ by solid state mixing. The mixture was then plastified and pelletised. Analagous preparations were made with micrometre sized $(\sim 0.5 \mu \mathrm{m}) \mathrm{ZnO}$. Each of these samples and a commercial varistor mixture were then sintered at $1050^{\circ} \mathrm{C}$ for $2 \mathrm{~h}$.

XRD measurements (Fig. 3) carried out on each of the samples sintered at $1050^{\circ} \mathrm{C}$ revealed the presence of spinel $\left(\mathrm{Zn}_{7} \mathrm{Sb}_{2} \mathrm{O}_{12}\right)$, bismuth rich $\left(\mathrm{Bi}_{2} \mathrm{O}_{3}\right)$ and zinc oxide phases. FESEM studies of the sintered samples (Fig. 4) indicate a smaller average grain size $(\sim 2 \mu \mathrm{m})$ in the material derived from nano- $\mathrm{ZnO}$ compared to the samples made from micrometre sized material $(\sim 3 \mu \mathrm{m})$ and to the commercial sample $(\sim 3 \mu \mathrm{m})$. EDX analysis (Fig. 5) revealed that three different phases could be readily identified in the microstructure of the material derived from nano- $\mathrm{ZnO}$. A $\mathrm{ZnO}$ phase was the most abundant which appeared as spherical or polygonal grains and contained a small amount of other dopants such as $\mathrm{Sb}, \mathrm{Cr}, \mathrm{Mn}, \mathrm{Co}$ and $\mathrm{Ni}$. A second phase present mainly at the triple points was also seen in the microstructure. EDX revealed that this phase contains a significant amount of $\mathrm{Zn}$ and $\mathrm{Sb}$ along with a small amount of $\mathrm{Cr}, \mathrm{Mn}, \mathrm{Bi}, \mathrm{Co}$ and $\mathrm{Ni}$ and this is attributed to a $\mathrm{Zn}_{7} \mathrm{Sb}_{2} \mathrm{O}_{12}$ phase. ${ }^{1,3,6,18-21}$ The white section observed in the microstructure near the intergranular region contains a large amount of $\mathrm{Bi}$, which is identified as the $\mathrm{Bi}_{2} \mathrm{O}_{3}$. These findings are consistent with previous literature reports, ${ }^{3,18-21}$ as it is known that above $650^{\circ} \mathrm{C} \mathrm{ZnO}$, $\mathrm{Bi}_{2} \mathrm{O}_{3}$ and $\mathrm{Sb}_{2} \mathrm{O}_{3}$ form a pyrochlore $\left(\mathrm{Zn}_{2} \mathrm{Bi}_{3} \mathrm{Sb}_{3} \mathrm{O}_{14}\right)$ phase. This then changes into the spinel $\left(\mathrm{Zn}_{7} \mathrm{Sb}_{2} \mathrm{O}_{12}\right)$ phase (equation (2)). The presence of spinel and bismuth rich phases are reported to play a significant role in the formation of varistors. ${ }^{18-20}$

$2 \mathrm{Zn}_{2} \mathrm{Bi}_{3} \mathrm{Sb}_{3} \mathrm{O}_{14}+17 \mathrm{ZnO} \stackrel{950-1050^{\circ} \mathrm{C}}{\longrightarrow} 3 \mathrm{Zn}_{7} \mathrm{Sb}_{2} \mathrm{O}_{12}+3 \mathrm{Bi}_{2} \mathrm{O}_{3}$

A significant difference between the samples was revealed by density measurements of the sintered bodies. Thus while the commercial sample showed $96 \%$ densification, and the sample prepared from micrometre sized $\mathrm{ZnO} 94 \%$, the material originating from nano- $\mathrm{ZnO}$ had achieved only $91 \%$. This is also apparent from the number of voids observable by FESEM. This is a notable disadvantage of this method compared with our earlier core-shell method, ${ }^{6}$ where $97 \%$ densification was obtained. It can also be seen from the microstructure (Fig. 4) that the final grain size of the sintered varistors made from nano- $\mathrm{ZnO}$ is only slightly smaller than in the other two samples, despite the fact that the reactant $\mathrm{ZnO}$ particles are about 10 times smaller. The grain growth in varistor ceramics is usually accompanied by the formation of $\mathrm{ZnO}-\mathrm{Bi}_{2} \mathrm{O}_{3}$ binary system during the liquid phase sintering. ${ }^{22,23}$ Bismuth oxide has a lower melting point $\left(656^{\circ} \mathrm{C}\right)$ and it is reported that the eutetic liquid temperature for $\mathrm{ZnO}-\mathrm{Bi}_{2} \mathrm{O}_{3}$ binary system is $740^{\circ} \mathrm{C}$. A significant enhancement of grain growth is expected above this temperature compared with the grain growth of pure $\mathrm{ZnO} .^{24,25}$ This is reported as due to the formation of a bismuth rich liquid phase along the grain boundaries, which increases the grain boundary mobility and thus facilitates the grain growth. ${ }^{24}$ This demonstrates that controlling the grain size during sintering at high temperature remains a real challenge. ${ }^{12,13,25}$ It is possible that other sintering procedures such as step sintering ${ }^{26,27}$ or microwave assisted sintering $^{28}$ might be applied to obtain a fully sintered varistor disc at a lower temperature.

\section{BREAKDOWN VOLTAGE}

The breakdown voltages of the sintered materials were measured at $1 \mathrm{~mA}$. These results (Fig. 6) show a breakdown voltage of $454 \pm 30 \mathrm{~V} \mathrm{~mm}^{-1}$ for commercial samples and $410 \pm 30 \mathrm{~V} \mathrm{~mm}^{-1}$ for varistors made from micrometre sized samples. Considerably higher breakdown voltage $\left(656 \pm 30 \mathrm{~V} \mathrm{~mm}^{-1}\right)$ was obtained with varistors made from nano- $\mathrm{ZnO}$. These results point towards the formation of more grain boundaries by nanostructuring. ${ }^{6,9,10,12}$ However, the sample derived from this nano-ZnO shows a disappointingly high leakage current, making it quite unsuitable for further industrial exploitation. A more favourable approach is to prepare varistors using $\mathrm{ZnO}$ made by a sol-gel route and adding the dopants using a solution technique to prepare core-shell type materials. ${ }^{6}$

\section{Conclusions}

Nano- $\mathrm{ZnO}$ has been produced by a solid state pyrolysis reaction and the precursors formed at various temperatures have been characterised by XRD. These results are consistent with the formation of anhydrous zinc oxalate as an intermediate. Considerably higher breakdown voltages were observed for varistors prepared from nano- $\mathrm{ZnO}$, which indicates a larger number of grain boundaries per unit area. Microstructural analysis revealed the presence of $\mathrm{ZnO}$, spinel and bismuth rich phases. Varistor samples prepared from the nano- $\mathrm{ZnO}$ sintered at $1050^{\circ} \mathrm{C}$ have a smaller grain size. Unfortunately the material has a low density and high leakage current compared to other novel samples prepared by our group.

\section{Acknowledgements}

The authors gratefully acknowledge the financial support of Enterprise Ireland (ARG/HE/1998/256), Littelfuse Ireland Ltd and HEA (PRTLI Materials Programme). We thank the Centre for Microscopy and Analysis, Trinity College Dublin and Mr Kevin Travers, Littelfuse Ireland, for help with electrical measurements.

\section{References}

1. T. K. GUPTA: J. Am. Ceram. Soc., 1990, 73, 1817-1840.

2. D. R. Clarke: J. Am. Ceram. Soc., 1999, 82, 485-502. 
3. L. M. LEVINSON and H. R. PHILIP: Ceram. Bull., 1986, 65, 639646.

4. M. MatsuoKa: Jpn. J. Appl. Phys., 1971, 10, 736-746.

5. G. H. WISEMAN: Key. Eng. Mater., 1998, 150, 209-218.

6. S. C. PILlAI, J. M. KELly, D. E. MCCORMACK, P. O'BRIEN and R. RAMESH: J. Mater. Chem., 2003, 13, 2586-2590.

7. R. PUyANe, F. TOAL and S. HAMPSHIRE: J. Sol Gel Sci. Technol., $1996,6,219-225$

8. G. WESTIN, A. EKSTRAND, N. NYGREN, R. OSTERLUND and P. MERKELBACH: J. Mater. Chem, 1994, 4, 615-621.

9. K. X. YA, H. YIN, T. M. DE and T. M. JING: Mater. Res. Bull., 1998, 33, $1703-1708$.

10. R. N. VISWANATH, S. RAMASAMY, R. RAMAMOORTHY, P. JAYAVEL and T. Nagarajan: Nanostruct. Mater., 1995, 6, 993-996.

11. S. Hishita, Y. YaO and S-I. SHIRASAKI: J. Am. Ceram. Soc., 1989, 72, $338-340$.

12. S. HINGORANI, V. PILlAi, P. KUMAR, M. S. MULTANI and D. O. SHAH: Mat. Res. Bull., 1993, 28, 1303-1310.

13. Y. LIN, Z. ZHANG, Z. TANG, F. YUAN and J. LI: Adv. Mater. Opt Electron., 1999, 9, 205.

14. R. J. SHEN, D. Z. JIA, Y. M. QIAO and J. Y. WANG: J. Inorg. Mater., $2001,16,625-629$

15. Z. WANG, H. ZHANG, L. ZHANG, J. YUAN, S. YAN and C. WANG: Nanotechnology, 2003, 14, $11-15$.
16. A. R. WEST: 'Solid state chemistry and its applications' 174; 1984, London, John Wiley \& Sons.

17. L. GUO, Y. JI, H. XU, Z. WU and P. SIMON: J. Mater. Chem., 2003, 13, $754-757$.

18. M. INADA: Jpn. J. Appl. Phys., 1980, 19, 409-419.

19. C.-H. LU, N. CHYI, H.-W. WONG and W.-J. HWANG: Mater. Chem Phys., 2000, 62, 164-168.

20. V. C. DE SAUSA, M. R. MORELLI, R, H, G. A. KIMINAMI and M. S. CASTRO: J. Mater. Sci. Mater. Electron., 2002, 13, 319-325.

21. A. BANARJEe, T. R. RAMMOHAN and M. J. PATNi: Mater. Res. Bull., 2001, 36, 1259- 1267

22. G. AGARWAL and R. F. SPEYER: J. Mater. Res., 1997, 12, $2447-$ 2454.

23. P. DURAn, F. CAPEl, J. TARTAJ and C. MOURe: J. Eur. Ceram. Soc., 2002, 22, $67-77$.

24. S. hingorani, D. O. SHAH and M. S. MUltani: J. Mater. Res., $1995,10,461-467$.

25. S. C. PILlAI, J. M. KELLY, D. E. MCCORMACK and R. RAMESH: J. Mater. Chem., 2004, 14, 1572-1578.

26. I. W. CHEN and X.-H. WANG: Nature, 2000, 404, 168-171.

27. p. duran, f. CAPel, J. TARtaj and C. moure: J. Am. Ceram. Soc., 2001, 84, 1661-1668.

28. J. G. P. BINNER, I. CARo and J. FIRKIns: J. Microw. Power Electromagn. Energy, 1999, 34, 131-136. 